$\S=-1$

\title{
Radioecological Monitoring of Adjacent Territories to the Former Semipalatinsk Nuclear Test Site, East Kazakhstan
}

\author{
Sergazy Duyssembaev, Ainur Serikova, Shyngys Suleimenov*, Nurgul Ikimbayeva, Assel Zhexenayeva, \\ Aizhan Akhemtzhanova, Zhibek Atambayeva
}

Shakarim State University of Semey, Kazakhstan

*Corresponding author e-mail: stat.stat2016@yandex.ru

\begin{abstract}
This paper presents the results of complex radioecological monitoring of the territories, which are situated near the Semipalatinsk Nuclear Test Site, East Kazakhstan region. The radiometric measurements showed that the concentration of radon and beta particles are below the permissible levels. EROA values of a radon in rooms fluctuates from $44 \mathrm{~Bq} / \mathrm{m}^{3}$ to $195 \mathrm{~Bq} / \mathrm{m}^{3}$. The measured values of fluency of betta-particles in all the studied points are less than $10 \mathrm{freq} / \mathrm{min} * \mathrm{~cm}^{2}$. A specific activity of radionuclides, such as Am-241, Cs-137 and $\mathrm{Pu}-239 / 240$ in soils, plant, water, meat and milk were evaluated.
\end{abstract}

Keywords: SNTS; radionuclide; nuclear test; radon; Cs-137.

\section{Introduction}

The Semipalatinsk Nuclear Test Site (SNTS) left a huge mark in the history of a nuclear race of the period of Cold War. On August 29 in 1949 , the Soviet Union made the first nuclear detonation in the territory of Kazakhstan. From this day, 40-year history of the Semipalatinsk exploring nuclear test site began. The 456 nuclear detonations among which 116 land and 340th underground explosions, led to a radio contamination not only the test site, but also adjacent territories where people live [1]. Leak of radioactive waste, discontent of the population - all this led to the anti-nuclear movement "Nevada-Semipalatinsk" with O. Suleymenov at the head. Having found independence, on August 29, 1991 the President of the Republic of Kazakhstan issued the decree on closing of SENTS. From this point, the Republic of Kazakhstan followed a way of non-proliferation and elimination of nuclear weapon and an arsenal [2,3].

On what the efficient equivalent exposure dose for the population exceeds $0,1 \mathrm{rem}$ for the entire period of tests are considered as the polluted territories. Depending on the size of an efficient equivalent dose, the polluted territories subdivided into four zones:

1) The zone of extreme radiation risk a part of the territory, which underwent radiation pollution, with a dose of impact on the population over 100 rem for the entire period of test. Entering a strip of the maximal seismic influence, is territories of the Sarzhal rura district of Abay district, the Dolon rural district of Beskaragay district, settlements Sarapan and Iza of the abolished ZhanasemeyRegion of East Kazakhstan.

2) A zone of the maximal radiation risk - a part of the territory, which underwent radiation pollution with a dose of impact on the population from 35 to 100 rem for the entire period of tests. Settlements of the Abaysky, Beskaragaysky and abolished Zhanasemey areas, Akbulak, Abralin, Algabas, Aynabulak, Karaolen and Tanat rural districts of the city of Semey of the East Kazakhstan region, Akzhar and Maldar rural districts of the May region of the Pavlodar region belong to a zone of the maximal radiation risk. 3) A zone of the increased radiation risk - a part of the territory, which underwent radiation pollution with a dose of impact on the population from 7 to $35 \mathrm{rem}$ for the entire period of tests. Settlements of Borodulikha, Zharma, Ayaguz, Glubokoye, Shemonaikha, Ulan districts, the cities of Semey, Kurchatov, UstKamenogorsk and Ridder of the East Kazakhstan region belong to this zone; Karkaralin district of the Karaganda region within the territory of the abolished Kazybek bi district, the May region of the Pavlodar region.

4) Zone of minimum radiation risk - a part of the territory which underwent radiation pollution with a dose of impact on the population from 0,1 to 7 rem for the entire period of tests. Settlements of Urdzhar abolished the Taskesken, Kokpekti, Aksuat, Zyryanovsk, Zaysan and Tarbagatai areas of East Kazakhstan region belong to a zone of minimum radiation risk; Karkaralinsk district of the Karaganda region, not including the territory of the abolished Kazybek bi district; Lebyazhin district of the Pavlodar region [4].

The statement of border of SENTS and return of a part of lands to an agricultural turn is one of successful steps of activity of the National nuclear center of the Republic of Kazakhstan. Nevertheless, many scientists and residents of settlements, adjacent to SENTS, consider hasty return of lands to national use, in connection with danger of migration of dangerous radionuclides in a biological line-up of a surrounding medium. In this regard, there is a need of carrying out monitoring of SENTS and identification of radiation-hazardous places [5-6].

The complication of a radiation situation in the territory of the East Kazakhstan, Pavlodar and Karaganda regions of the Republic of Kazakhstan caused by activity of the former Semipalatinsk. Exploring nuclear test site, production and processing of minerals with the increased content of radioelements, natural radioactive anomalies in the places of residence of the population and in the underground waters used for drinking water supply. Besides, there are sites where radioactive waste placed [7]. 
Researches of a radio ecological situation, influence of nuclear tests on a surrounding medium and human health outside the ground, were conducted since the beginning of tests, but they had the irregular character and results of researches were not systematized [8].

According to the scientific different countries of the world, loss of radioactive substances accepted global character and served as the biosphere radio-contamination reason. Radionuclides dropping out on the Earth's surface found in the atmosphere, the soil, water, plants, in organisms of animals and the person creating additional radiation of alive organisms. Pollution of foodstuff causes receipt of radionuclide in a human body and its radiation. On it intake of radioactive substances to the external environment caused and continues to cause quite reasonable alarm and concern of world community [9-12].

The purpose of our researches is in the conditions of the former SENTS and in adjacent territories to carry out radio environmental monitoring - the system of the regular long-lived overseeing by maintenance and migration of radionuclides from a chain the soil water - a stern - animals - production of livestock production for the purpose of assessment and the forecast of their biological effect for farm animals, levels of radio nuclide pollution and safety of production received from them.

The conducted researches will help to make the detailed card of pollution by radionuclides and heavy metals of the explored territory on the basis of the radiological analysis of the surface layers of the soil and water sources, to study extent of accumulation of radioelements in the soil, vegetation, potable water and food of the studied settlements. The received results will be applied when developing a package of measures for ensuring radiation safety.

For achievement of a goal we selected nearby settlements to the ground from different zones of radiation risk:

from an extraordinary zone of radiation risk: villages of Bodene, Sarapan, Sarzhal, Dolon, Mostik, Zhanan.

from the raised zone of radiation risk: cities of Semey, Ayaguz, villages of Novopokrovka, Sagyr, Karasu, Kiikkashkan, Shynkozha.

from the maximal zone of radiation risk: villages Beskaragay, Semiyarka, Kaynar, Akzhar, Kaskabulak, Abrala, Znamenka, Kokbay, Begen.

from a minimum zone of radiation risk: village of Zhantike, Kokterek, Karkarala, Mailing, Oyshilik, Makanshy, Kokzhyra, Akku.

\section{Materials and methods}

For the analysis of a radio ecological situation in the territory of adjacent to SENTS 30 stationary checkpoints from which tests of the soil, water, vegetation and animal products were selected are created.

Before sample drawing in checkpoints radiometric control was carried out. For carrying out radiometric control in the explored territories devices and metering devices which annually undergo the state checking were used. Preparation for instrumental measurements were carried out according to maintenance instructions of these devices. Dosage rate of a gamma radiation, fluence of beta particles were determined by state standard specifications 26307-84, 26306-84. Measurements of the equivalent equilibrium volume activity of a radon EEVAR and thoron carried out on the open area and in air of premises of the explored territories. Further we selected tests of the soil, plants, water and livestock products (milk and meat) in the explored settlements. Sample drawing was carried out on the staticized interstate standards and standards of the Republic of Kazakhstan: GOST 17.4.3.01-83 Conservation. Soils. Common requirements to sample drawing, GOST 27262-87 Phytogenesis Stern, methods of sample drawing, ST of RK GOST P 51592-2003 Water. Common requirements to sample drawing. Sample drawing of meat and milk and dairy products was carried out on ST of RK 1623-2007 Radiation monitoring. Foodstuff. Sample drawing, analysis and hygienic assessment [42].
Preparation of tests and measurement on radio nuclide structure it was carried out by techniques:

A technique of determination of content of simulated radionuclides of plutonium - $(239+240)$, strontium-90 in objects of a surrounding medium (soils, soils, ground deposits and plants) [43];

A technique of determination of content of simulated radionuclides of plutonium - $(239+240)$, strontium-90 and cesium-137 in natural waters by method of concentrating [44];

Activity of radionuclides in volume exemplars. A technique of realization of measurements on a gamma spectrometer [45];

- ST of RK 1623-2007 Radiation monitoring. Foodstuff [42].

Measurements taken on alpha and gamma spectrometers of CANBERRA. The selected tests brought to testing regional laboratory of the engineering profile "Scientific Center of Radio Ecological Researches". Preparation of tests it carried out on operating techniques. For definition of cesium-137 and americium-241 of test of the soil, plants dried up to an air-dried state, periodic hashing. Further tests of the soil crushed by means of a pestle with a mortar and sifted through bolters with a diameter of $2 \mathrm{~mm}$ and tests of plants crushed on the blender. The shot was placed in the measuring capacity (the mass of a shot depended on the volume of a gaged vessel) and measured radionuclide structure on a gamma spectrometer of CANBERRA with the electro cooling detector. Tests of water filtered via the "The White Ribbon" filter, then preserved hydrogen nitrate in calculation $3 \mathrm{ml}$ on 11 of test $(\mathrm{pH}<1)$. $\mathrm{pH}$ controlled according to indicator paper. Tests of meat cut on shallow pieces, crushed by means of the electric meat grinder, and placed in Marinelli's vessel, tests of milk poured from bottles in Marinelli's vessels. Further tests measured on a gamma spectrometer.

To determine the content of plutonium $239+340$ in tests the stageby-stage radiochemical analysis carried out:

1 stage - Preparation of tests (an exsiccation, an ashing);

2 stage - the Lixiviation of tests with acids;

3 stage - the Sorption and a desorption on chromatographic columns;

4 stage - a plutonium Deposition.

After the radiochemical analysis of test measured on an alpha-ray spectrometer.

\subsection{Statistical Analysis}

Statistical analysis was performed using Statistica 12.0 (STATISTICA, 2014; StatSoft Inc., Tulsa, OK, USA). The differences between samples were evaluated using ANOVA method. The differences were considered to be statistically significant at $\mathrm{p} \leq$ 0.05

\section{Results and discussions}

Radiation examination of a day surface conducted in the Searching mode. Places with the maximal values of capacities of air dose (further - CAD) were allocated as sampling points of the soil and plants for a research for a content of natural and simulated radionuclides.

Results of radiation inspection of a day surface are presented in figures $1,2,3$.

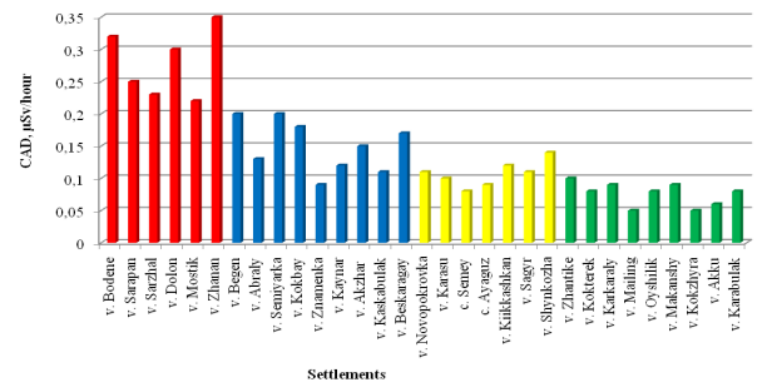

Figure 1 - CAD values of a day surface of the studied points 
Apparently from the figure 1 , made the CAD level in a zone of extreme radiation risk from $0,18 \mu \mathrm{Sv} /$ hour to $0,35 \mu \mathrm{Sv} /$ hour. In a zone of the maximal radiation risk from $0,09 \mu \mathrm{Sv} /$ hour to 0,2 $\mu \mathrm{Sv} /$ hour. In a zone of the increased radiation risk from 0,08 $\mu \mathrm{Sv} /$ hour to $0,14 \mu \mathrm{Sv} / \mathrm{hour}$. In a zone of minimum radiation risk made from $0,05 \mu \mathrm{Sv} /$ hour to $0,1 \mu \mathrm{Sv} /$ hour.
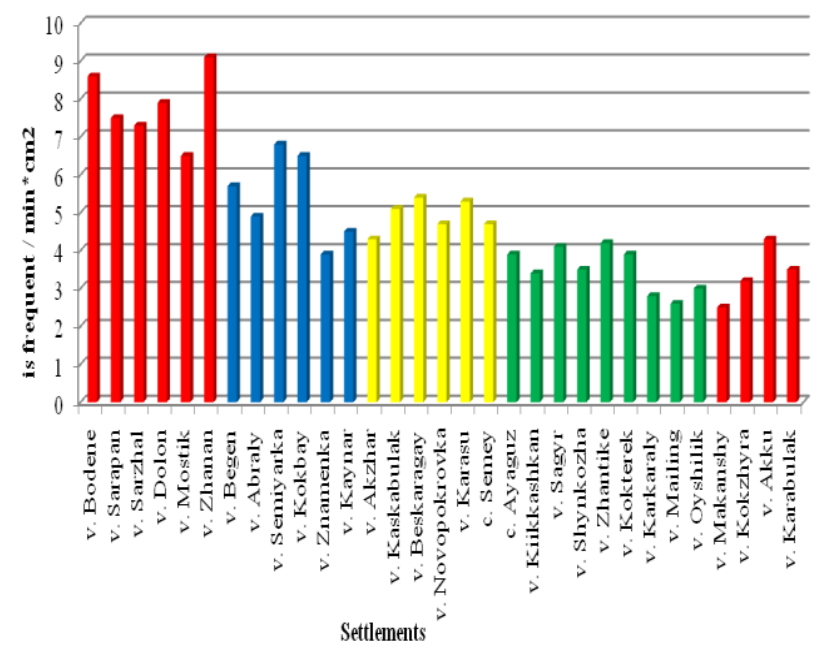

Figure 2 - Values of density of betta-particles of a surface of the studied points

Made the measured values of fluence of betta-particles in all studied points $<10$ it is frequent $/ \mathrm{min}^{*} \mathrm{~cm} 2$. In a zone of extreme radiation risk fluence of beta particles from 6,5 it is frequent $/$ min* $\mathrm{cm} 2$ to 9,1 is frequent $/ \mathrm{min}^{*} \mathrm{~cm}^{2}$. In a zone of the maximal radiation risk from 3,9 it is frequent / $\mathrm{min}^{*} \mathrm{~cm} 2$ to 6,8 is frequent / $\min * \mathrm{~cm} 2$. In a zone of the increased radiation risk from 3,4 it is frequent $/ \min * \mathrm{~cm} 2$ to 5,3 is frequent $/ \mathrm{min} * \mathrm{~cm} 2$. In a zone of minimum radiation risk from 2,5 it is frequent $/ \mathrm{min} * \mathrm{~cm} 2$ to 4,3 is frequent $/ \min * \mathrm{~cm} 2$.

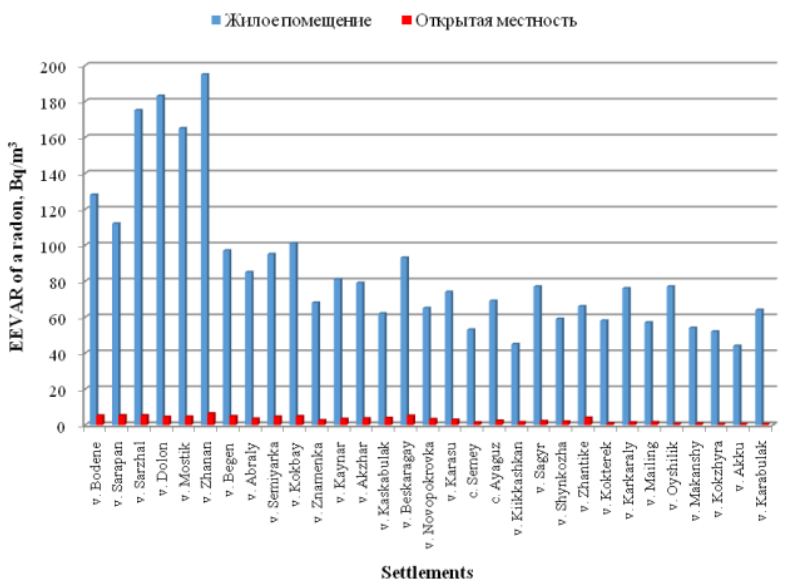

Figure 3 - EEC of radon in studied areas

The equilibrium equivalent concentration (EEC) of radon in the open area in all studied points made from 0,5 to $6,3 \mathrm{~Bq} / \mathrm{m}^{3}$. The maximal content of radon Zhanan of $195 \mathrm{~Bq} / \mathrm{m} 3$ is found in a wintering.

EEC of radon in premises fluctuates from $44 \mathrm{~Bq} / \mathrm{m}^{3}$ to $195 \mathrm{~Bq} / \mathrm{m}^{3}$. In a zone of extreme radiation risk from $112 \mathrm{~Bq} / \mathrm{m}^{3}$ to $195 \mathrm{~Bq} / \mathrm{m}^{3}$. In a zone of the maximal radiation risk the content of radon is from $62 \mathrm{~Bq} / \mathrm{m} 3$ up to $101 \mathrm{~Bq} / \mathrm{m}^{3}$. In a zone of the increased radiation risk the content of radon from $53 \mathrm{~Bq} / \mathrm{m}^{3}$ to $77 \mathrm{~Bq} / \mathrm{m}^{3}$. In a zone of minimum radiation risk from $44 \mathrm{~Bq} / \mathrm{m}^{3}$ to $77 \mathrm{~Bq} / \mathrm{m}^{3}$.

Radon comes to the atmosphere at division of kernels of U-238 and kernels of Th-232. The main source of intake of radon in air of rooms is the geological space under the building. A radon easily gets into rooms on permeable zones of crust. The building with a gas-permeable floor built on the land surface can increase a stream of the radon which is coming out the earth to 10 times at the expense of an air pressure drop in rooms of the building and the atmosphere. At respiration millions of radioactive atoms of a radon get into lungs in one minute, they selectively collect in some bodies and fabrics, especially in a hypophysis and bark of the adrenal glands, these two major endocrine glands defining hormonal activity of an organism and regulating activity of the autonomic nervous system. Concentrate also in heart, a liver and others, vitals. Being dissolved in blood and a lymph, a radon and products of its disintegration are quickly delivered on all body and lead to internal massive radiation. The danger of a radon besides the functional violations caused by it (asthmatic attacks of suffocation, migraine, dizziness, nausea, a depression etc) is also that owing to internal radiation of pulmonary fabric it is capable to cause cancer of lungs.

Results of alpha and gamma and spectrometer analyses of tests of a surrounding medium and livestock products are given in tables $1,2,3,4,5$.

Table 1: The maintenance of radionuclides in soils

\begin{tabular}{|c|c|c|c|}
\hline \multirow{2}{*}{$\begin{array}{c}\text { Inhabited } \\
\text { point }\end{array}$} & \multicolumn{3}{|c|}{ Specific activity of radionuclides, $\mathrm{Bq} / \mathrm{kg}$} \\
\hline & $\mathrm{Am}-241$ & Cs-137 & $\mathrm{Pu}-239 / 240$ \\
\hline v. Bodene & $18,6 \pm 0,5$ & $1322,2 \pm 5,3$ & $2,2 \pm 0,2$ \\
\hline v. Sarapan & $9,0 \pm 0,2$ & $62,2 \pm 5,2$ & $1,4 \pm 0,2$ \\
\hline v. Sarzhal & $15,3 \pm 0,5$ & $35,5 \pm 1$ & $0,5 \pm 0,2$ \\
\hline v. Dolon & $79 \pm 1$ & $94 \pm 0,3$ & $1,8 \pm 0,3$ \\
\hline v. Mostik & $22 \pm 1,2$ & $42 \pm 0,5$ & $0,2 \pm 0,1$ \\
\hline v. Zhanan & $91,5 \pm 1,8$ & $3658,6 \pm 22,5$ & $11,4 \pm 0,3$ \\
\hline v. Begen & $13,4 \pm 0,2$ & $45,6 \pm 3,4$ & $3,8 \pm 0,3$ \\
\hline v. Abraly & $13,6 \pm 0,3$ & $32,3 \pm 0,2$ & $2,2 \pm 0,5$ \\
\hline v. Semiyarka & $17 \pm 1$ & $25 \pm 1$ & $1,3 \pm 0,1$ \\
\hline v. Kokbay & $4 \pm 0,2$ & $15 \pm 1$ & $0,8 \pm 0,2$ \\
\hline v. Znamenka & $0,4 \pm 0,2$ & $8,5 \pm 0,2$ & $<0,05$ \\
\hline v. Kaynar & $1,9 \pm 0,1$ & $9 \pm 1$ & $1,2 \pm 0,4$ \\
\hline v. Akzhar & $0,4 \pm 0,2$ & $15 \pm 1$ & $0,5 \pm 1,0$ \\
\hline v. Kaskabulak & $0,7 \pm 0,2$ & $14 \pm 1$ & $1,7 \pm 1,2$ \\
\hline v. Beskaragay & $6 \pm 1$ & $21 \pm 1$ & $<0,05$ \\
\hline v. Novopokrovka & $2,3 \pm 0,3$ & $2,8 \pm 0,2$ & $<0,05$ \\
\hline v. Karasu & $1,1 \pm 0,4$ & $3,9 \pm 1$ & $<0,062$ \\
\hline c. Semey & $8,3 \pm 0,5$ & $10 \pm 1$ & $<0,07$ \\
\hline c. Ayaguz & $1,7 \pm 0,2$ & $5,3 \pm 0,4$ & $<0,043$ \\
\hline v. Kiikkashkan & $0,8 \pm 0,2$ & $1,2 \pm 0,2$ & $0,06 \pm 0,01$ \\
\hline v. Sagyr & $1,1 \pm 0,3$ & $5,2 \pm 1$ & $<0,02$ \\
\hline v. Shynkozha & $1,5 \pm 0,2$ & $8 \pm 1$ & $<0,01$ \\
\hline v. Zhantike & $1,1 \pm 0,3$ & $12 \pm 1$ & $1,1 \pm 1,0$ \\
\hline v. Kokterek & $0,8 \pm 0,3$ & $0,8 \pm 0,2$ & $<0,009$ \\
\hline v. Karkaraly & $0,5 \pm 0,3$ & $1,6 \pm 1$ & $<0,006$ \\
\hline v. Mailing & $0,3 \pm 0,1$ & $1,9 \pm 1$ & $<0,008$ \\
\hline v. Oyshilik & $0,7 \pm 0,2$ & $1,4 \pm 1$ & $<0,01$ \\
\hline v. Makanshy & $0,5 \pm 0,2$ & $1,7 \pm 0,5$ & $<0,005$ \\
\hline v. Kokzhyra & $0,5 \pm 0,3$ & $0,5 \pm 0,1$ & $<0,0072$ \\
\hline v. Akku & $0,4 \pm 0,2$ & $13 \pm 1$ & $<0,005$ \\
\hline v. Karabulak & $0,32 \pm 0,1$ & $0,9 \pm 0,1$ & $<0,0075$ \\
\hline
\end{tabular}

According to table 1 the specific activity of radionuclides in tests of the soil does not exceed the extreme admissible concentration. In an extraordinary zone of radiation risk the level of a specific activity Am-241 from 9,0 $\pm 0,2 \mathrm{~Bq} / \mathrm{kg}$ to $91,5 \pm 1,8 \mathrm{~Bq} / \mathrm{kg}, \mathrm{Cs}-137$ from $35,5 \pm 1 \mathrm{~Bq} / \mathrm{kg}$ to $3658,6 \pm 22,5 \mathrm{~Bq} / \mathrm{kg}, \mathrm{Pu}-239 / 240$ from $0,2 \pm 0,1 \mathrm{~Bq} / \mathrm{kg}$ to $11,4 \pm 0,3 \mathrm{~Bq} / \mathrm{kg}$.

In the maximal zone of radiation risk specific activity of radionuclides: Am-241 from $0,4 \pm 0,2 \mathrm{~Bq} / \mathrm{kg}$ to $17 \pm 1 \mathrm{~Bq} / \mathrm{kg}$, Cs-137 from $8,5 \pm 0,2 \mathrm{~Bq} / \mathrm{kg}$ to $45,6 \pm 3,4 \mathrm{~Bq} / \mathrm{kg}, \mathrm{Pu}-239 / 240$ from $0,05 \mathrm{~Bq} / \mathrm{kg}$ to $3,8 \pm 0,3$ Бк/кг.

In the raised zone of radiation risk the maintenance of radionuclides of Am-241 from $0,8 \pm 0,2 \mathrm{~Bq} / \mathrm{kg}$ to $8,3 \pm 0,5 \mathrm{~Bq} / \mathrm{kg}, \mathrm{Cs}-137$ from $1,2 \pm 0,2 \mathrm{~Bq} / \mathrm{kg}$ to $10 \pm 1 \mathrm{~Bq} / \mathrm{kg}, \mathrm{Pu}-239 / 240$ from $0,01 \mathrm{~Bq} / \mathrm{kg}$ to $0,07 \mathrm{~Bq} / \mathrm{kg}$.

In tests of a minimum zone of radiation defeat activity of radionuclides: Am-241 from $0,3 \pm 0,1 \mathrm{~Bq} / \mathrm{kg}$ to $1,1 \pm 0,3 \mathrm{~Bq} / \mathrm{kg}, \mathrm{Cs}-137$ from $0,5 \pm 0,1 \mathrm{~Bq} / \mathrm{kg}$ to $13 \pm 1 \mathrm{~Bq} / \mathrm{kg}, \mathrm{Pu}-239 / 240$ from 0,0072 $\mathrm{Bq} / \mathrm{kg}$ to $1,1 \square 1,0$ of $\mathrm{Bq} / \mathrm{kg}$. 
We investigated tests of plants of the above-stated points.

Table 2: The maintenance of radionuclides in tests of plants

\begin{tabular}{|l|c|c|c|}
\hline \multirow{2}{*}{\multicolumn{1}{|c|}{$\begin{array}{c}\text { Inhabited } \\
\text { point }\end{array}$}} & \multicolumn{3}{|c|}{ Specific activity of radionuclides, Bq/kg } \\
\cline { 2 - 4 } & Am-241 & Cs-137 & Pu-239/240 \\
\hline v. Bodene & $1,5 \pm 0,2$ & $58 \pm 0,5$ & $0,7 \pm 0,1$ \\
\hline v. Sarapan & $2,4 \pm 0,4$ & $29 \pm 0,3$ & $0,5 \pm 0,1$ \\
\hline v. Sarzhal & $1,5 \pm 0,3$ & $2,8 \pm 0,4$ & $<0,7$ \\
\hline v. Dolon & $15,2 \pm 0,5$ & $58 \pm 0,5$ & $<0,5$ \\
\hline v. Mostik & $3,5 \pm 0,3$ & $19,7 \pm 0,5$ & $<0,5$ \\
\hline v. Zhanan & $25,8 \pm 0,2$ & $1150,3 \pm 10$ & $2,2 \pm 0,2$ \\
\hline v. Begen & $4,5 \pm 0,2$ & $18,2 \pm 1,2$ & $<0,5$ \\
\hline v. Abraly & $5,5 \pm 0,2$ & $6,2 \pm 0,4$ & $<0,8$ \\
\hline v. Semiyarka & $4,9 \pm 0,2$ & $8,8 \pm 0,5$ & $<0,2$ \\
\hline v. Kokbay & $<1$ & $2,3 \pm 0,5$ & $<0,1$ \\
\hline v. Znamenka & $<0,08$ & $2,1 \pm 0,2$ & $<0,005$ \\
\hline v. Kaynar & $<1$ & $0,9 \pm 0,1$ & $<0,5$ \\
\hline v. Akzhar & $<0,1$ & $1,1 \pm 0,1$ & $<0,2$ \\
\hline v. Kaskabulak & $<0,1$ & $5,1 \pm 0,2$ & $<0,8$ \\
\hline v. Beskaragay & $1,8 \pm 0,2$ & $4,8 \pm 0,3$ & $<0,002$ \\
\hline v. Novopokrovka & $<0,5$ & $0,7 \pm 0,2$ & $<0,1$ \\
\hline v. Karasu & $<0,3$ & $0,8 \pm 0,2$ & $<0,01$ \\
\hline c. Semey & $1,2 \pm 0,2$ & $<1$ & $<0,05$ \\
\hline c. Ayaguz & $<0,8$ & $<0,5$ & $<0,01$ \\
\hline v. Kiikkashkan & $<0,2$ & $<1$ & $<0,5$ \\
\hline v. Sagyr & $<0,5$ & $1,3 \pm 0,2$ & $<0,0005$ \\
\hline v. Shynkozha & $<0,5$ & $1,8 \pm 0,2$ & $<0,0005$ \\
\hline v. Zhantike & $<0,5$ & $<0,8$ & $0,2 \pm 0,01$ \\
\hline v. Kokterek & $<0,1$ & $<0,2$ & $<0,003$ \\
\hline v. Karkaraly & $<0,3$ & $0,5 \pm 0,1$ & $<0,002$ \\
\hline v. Mailing & $<0,05$ & $<0,5$ & $<0,001$ \\
\hline v. Oyshilik & $<0,05$ & $<0,5$ & $<0,005$ \\
\hline v. Makanshy & $<0,05$ & $<0,5$ & $<0,002$ \\
\hline v. Kokzhyra & $<0,05$ & $<0,2$ & $<0,002$ \\
\hline v. Akku & $<0,05$ & $<0,5$ & $<0,002$ \\
\hline v. Karabulak & $<0,03$ & $<0,5$ & $<0,001$ \\
\hline On these results & 2605 \\
\hline
\end{tabular}

On these results of table 2 in tests of plants a specific activity of radionuclides in an extraordinary zone of radiation risk Am-241 from $1,5 \pm 0,2 \mathrm{~Bq} / \mathrm{kg}$ to $25,8 \pm 0,2 \mathrm{~Bq} / \mathrm{kg}$, Cs-137 from $2,8 \pm 0,4$ $\mathrm{Bq} / \mathrm{kg}$ to $1150,3 \pm 10 \mathrm{~Bq} / \mathrm{kg}, \mathrm{Pu}-239 / 240$ from $0,5 \mathrm{~Bq} / \mathrm{kg}$ to $2,2 \pm 0,2$ $\mathrm{Bq} / \mathrm{kg}$.

In the maximal zone of radiation risk specific activity of radionuclides: Am-241 from 0,3 Bq/kg to $1,8 \pm 0,2 \mathrm{~Bq} / \mathrm{kg}$, Cs- 137 from $0,5 \mathrm{~Bq} / \mathrm{kg}$ to $4,8 \pm 0,3 \mathrm{~Bq} / \mathrm{kg}, \mathrm{Pu}-239 / 240$ from $0,0005 \mathrm{~Bq} / \mathrm{kg}$ to $0,1 \mathrm{~Bq} / \mathrm{kg}$.

In the raised zone of radiation risk the maintenance of radionuclides of $\mathrm{Am}-241$ from $0,08 \mathrm{~Bq} / \mathrm{kg}$ to $5,5 \pm 0,2 \mathrm{~Bq} / \mathrm{kg}$, Cs137 from $0,9 \pm 0,1 \mathrm{~Bq} / \mathrm{kg}$ to $18,2 \pm 1,2 \mathrm{~Bq} / \mathrm{kg}, \mathrm{Pu}-239 / 240$ from $0,005 \mathrm{~Bq} / \mathrm{kg}$ to $0,8 \mathrm{~Bq} / \mathrm{kg}$.

In tests of a minimum zone of radiation defeat specific activity of radionuclides: $\mathrm{Am}-241$ from $0,03 \mathrm{~Bq} / \mathrm{kg}$ to $0,5 \mathrm{~Bq} / \mathrm{kg}$, Cs- 137 from $0,2 \mathrm{~Bq} / \mathrm{kg}$ to $0,5 \pm 0,1 \mathrm{~Bq} / \mathrm{kg}, \mathrm{Pu}-239 / 240$ from $0,001 \mathrm{~Bq} / \mathrm{kg}$ to $0,2 \pm 0,01 \mathrm{~Bq} / \mathrm{kg}$.

These data demonstrate that a part of radionuclides pass from the soil into plants.

Table 3: The maintenance of radionuclides in water tests

\begin{tabular}{|l|c|c|c|}
\hline \multirow{2}{*}{ Inhabited point } & \multicolumn{3}{|c|}{ Volume activity of radionuclides, Bq/1 } \\
\cline { 2 - 4 } & Am-241 & Cs-137 & Pu-239/240 \\
\hline v. Bodene & $0,08 \pm 0,02$ & $2,2 \pm 0,1$ & $<0,01$ \\
\hline v. Sarapan & $0,07 \pm 0,01$ & $1,5 \pm 0,4$ & $<0,007$ \\
\hline v. Sarzhal & $0,15 \pm 0,03$ & $1,1 \pm 0,1$ & $<0,005$ \\
\hline v. Dolon & $0,052 \pm 0,01$ & $1,2 \pm 0,2$ & $<0,008$ \\
\hline v. Mostik & $0,05 \pm 0,01$ & $<0,5$ & $<0,004$ \\
\hline v. Zhanan & $0,1 \pm 0,01$ & $2,5 \pm 0,1$ & $<0,05$ \\
\hline v. Begen & $0,06 \pm 0,01$ & $<0,18$ & $<0,003$ \\
\hline v. Abraly & $0,082 \pm 0,02$ & $<0,12$ & $<0,005$ \\
\hline v. Semiyarka & $<0,02$ & $<0,13$ & $<0,002$ \\
\hline v. Kokbay & $<0,02$ & $<0,09$ & $<0,002$ \\
\hline v. Znamenka & $<0,03$ & $<0,12$ & $<0,001$ \\
\hline v. Kaynar & $0,04 \pm 0,01$ & $<0,11$ & $<0,005$ \\
\hline v. Akzhar & $<0,02$ & $<0,6$ & $<0,002$ \\
\hline v. Kaskabulak & $<0,01$ & $<0,7$ & $<0,0021$ \\
\hline v. Beskaragay & $<0,01$ & $<0,08$ & $<0,004$ \\
\hline
\end{tabular}

\begin{tabular}{|l|c|c|c|}
\hline $\begin{array}{l}\text { v. Novo- } \\
\text { pokrovka }\end{array}$ & $<0,02$ & $<0,07$ & $<0,0055$ \\
\hline v. Karasu & $<0,01$ & $<0,1$ & $<0,006$ \\
\hline c. Semey & $0,06 \pm 0,01$ & $<0,8$ & $<0,003$ \\
\hline c. Ayaguz & $<0,05$ & $<0,14$ & $<0,002$ \\
\hline v. Kiikkashkan & $<0,02$ & $<0,11$ & $<0,005$ \\
\hline v. Sagyr & $<0,02$ & $<0,06$ & $<0,0012$ \\
\hline v. Shynkozha & $<0,03$ & $<0,08$ & $<0,0015$ \\
\hline v. Zhantike & $<0,01$ & $<0,05$ & $<0,0014$ \\
\hline v. Kokterek & $<0,01$ & $<0,02$ & $<0,0008$ \\
\hline v. Karkaraly & $<0,04$ & $<0,04$ & $<0,002$ \\
\hline v. Mailing & $<0,005$ & $<0,01$ & $<0,0003$ \\
\hline v. Oyshilik & $<0,003$ & $<0,03$ & $<0,0002$ \\
\hline v. Makanshy & $<0,003$ & $<0,04$ & $<0,004$ \\
\hline v. Kokzhyra & $<0,01$ & $<0,05$ & $<0,0005$ \\
\hline v. Akku & $<0,004$ & $<0,02$ & $<0,0005$ \\
\hline v. Karabulak & $<0,002$ & $<0,03$ & $<0,0002$ \\
\hline V.
\end{tabular}

Volume activity of radionuclides in a zone of extreme radiation risk made Am-241 from 0,05 to 0,15 Bq/1, Cs-137 from 0,5 Bq/l to $2,5 \mathrm{~Bq} / \mathrm{l}, \mathrm{Pu}-239 / 240$ from $0,004 \mathrm{~Bq} / \mathrm{l}$ to $0,05 \mathrm{~Bq} / \mathrm{l}$.

In a zone of the increased radiation risk of Am-241 from 0,01 to 0,06 Bq/l, Cs-137 from 0,07 Bq/l to 0,14 Bq/l, Pu-239/240 from $0,002 \mathrm{~Bq} / \mathrm{l}$ to $0,006 \mathrm{~Bq} / \mathrm{l}$.

In a zone of the maximal radiation risk Am-241 from 0,01 to $0,082 \mathrm{~Bq} / \mathrm{l}, \mathrm{Cs}-137$ from $0,08 \mathrm{~Bq} / \mathrm{l}$ to $0,18 \mathrm{~Bq} / \mathrm{l}, \mathrm{Pu}-239 / 240$ from $0,001 \mathrm{~Bq} / 1$ to $0,005 \mathrm{~Bq} / \mathrm{l}$.

In a zone of minimum radiation risk $\mathrm{Am}-241$ from 0,002 to 0,04Bq/l, Cs-137 from 0,01 Bq/l to 0,05 Bq/l, Pu-239/240 from $0,0002 \mathrm{~Bq} / \mathrm{l}$ to $0,004 \mathrm{~Bq} / \mathrm{l}$.

Results of researches show that in tests of water there are radionuclides at quantities, it is much less than the levels of intervention (GN No. 201, Cs137 - 11 Bq/kg, Am241 - 0,69Bq/kg, Pu239/240 - $0,55 \mathrm{~Bq} / \mathrm{l})$. However their presence in these regions is required carrying out padding researches.

The plants growing on fields and meadows are sources of radioactive substances in an organism of farm animals and pollution of the products (meat, milk) received from them. The meat and dairy cattle in days eats a grass from very big area - to 160 sq.m (on one cow) and consequently, radionuclides intensively get to an organism of animals. With milk of cows, about $1 \%$ of cesium and the strontium, which came to an organism in their daily diet, removed.

With dairy products, radioelements get into a human body and cause internal radiation of various bodies and fabrics that leads to increase in possibility of various diseases.

Table 4: The maintenance of radionuclides in tests of milk

\begin{tabular}{|l|c|c|c|}
\hline \multirow{2}{*}{ Inhabited point } & \multicolumn{3}{|c|}{ Volume activity of radionuclides, Bq/1 } \\
\cline { 2 - 4 } & Am-241 & Cs-137 & Pu-239/240 \\
\hline v. Bodene & $<0,5$ & $7,7 \pm 0,2$ & $0,056 \pm 0,01$ \\
\hline v. Sarapan & $<0,5$ & $8,2 \pm 0,1$ & $0,034 \pm 0,01$ \\
\hline v. Sarzhal & $0,7 \pm 0,1$ & $4,8 \pm 0,6$ & $<0,012$ \\
\hline v. Dolon & $0,6 \pm 0,1$ & $9,3 \pm 0,2$ & $<0,005$ \\
\hline v. Mostik & $<0,5$ & $3,2 \pm 0,2$ & $<0,001$ \\
\hline v. Zhanan & $2,3 \pm 0,2$ & $12,3 \pm 0,3$ & $0,062 \pm 0,01$ \\
\hline v. Begen & $0,18 \pm 0,02$ & $9,2 \pm 0,3$ & $0,032 \pm 0,001$ \\
\hline v. Abraly & $0,16 \pm 0,03$ & $5,6 \pm 0,1$ & $0,008 \pm 0,002$ \\
\hline v. Semiyarka & $0,12 \pm 0,01$ & $1,75 \pm 0,2$ & $0,022 \pm 0,002$ \\
\hline v. Kokbay & $0,1 \pm 0,02$ & $<0,5$ & $<0,003$ \\
\hline v. Znamenka & $0,15 \pm 0,01$ & $<0,5$ & $<0,002$ \\
\hline v. Kaynar & $0,4 \pm 0,01$ & $1,8 \pm 0,2$ & $0,007 \pm 0,001$ \\
\hline v. Akzhar & $<0,2$ & $<0,8$ & $0,008 \pm 0,001$ \\
\hline v. Kaskabulak & $<0,2$ & $1,5 \pm 0,2$ & $<0,003$ \\
\hline v. Beskaragay & $0,11 \pm 0,01$ & $<0,5$ & $<0,005$ \\
\hline v. Novopokrovka & $0,3 \pm 0,02$ & $0,5 \pm 0,1$ & $<0,004$ \\
\hline v. Karasu & $0,21 \pm 0,02$ & $0,8 \pm 0,1$ & $<0,003$ \\
\hline c. Semey & $<0,2$ & $0,5 \pm 0,02$ & $0,006 \pm 0,001$ \\
\hline c. Ayaguz & $<0,03$ & $<0,2$ & $<0,002$ \\
\hline v. Kiikkashkan & $<0,02$ & $0,45 \pm 0,02$ & $<0,002$ \\
\hline v. Sagyr & $<0,02$ & $0,6 \pm 0,2$ & $<0,002$ \\
\hline v. Shynkozha & $<0,01$ & $<0,5$ & $<0,005$ \\
\hline v. Zhantike & $0,019 \pm 0,002$ & $1,7 \pm 0,02$ & $<0,004$ \\
\hline v. Kokterek & $0,09 \pm 0,01$ & $<0,5$ & $<0,005$ \\
\hline v. Karkaraly & $<0,1$ & $<0,2$ & $<0,0001$ \\
\hline
\end{tabular}




\begin{tabular}{|l|c|c|c|}
\hline v. Mailing & $<0,03$ & $<0,3$ & $<0,0005$ \\
\hline v. Oyshilik & $<0,02$ & $<0,2$ & $<0,0003$ \\
\hline v. Makanshy & $<0,03$ & $<0,1$ & $<0,0002$ \\
\hline v. Kokzhyra & $<0,017$ & $<0,1$ & $<0,0005$ \\
\hline v. Akku & $<0,013$ & $1,12 \pm 0,03$ & $<0,0003$ \\
\hline v. Karabulak & $<0,015$ & $<0,1$ & $<0,0005$ \\
\hline
\end{tabular}

Radionuclides contain in the studied tests of milk, but does not exceed admissible levels. By results of researches in a zone of extreme radiation risk made Am-241 from 0,5 to 2,3 $\pm 0,2 \mathrm{~Bq} / \mathrm{l}$, Cs137 from $3,2 \pm 0,2 \mathrm{~Bq} / \mathrm{l}$ to $12,3 \pm 0,3 \mathrm{~Bq} / \mathrm{l}, \mathrm{Pu}-239 / 240$ from 0,001 $\mathrm{Bq} / \mathrm{l}$ to $0,062 \pm 0,01 \mathrm{~Bq} / \mathrm{l}$.

In a zone of the increased radiation risk of Am-241 from 0,01 to $0,3 \mathrm{~Bq} / \mathrm{l}, \mathrm{Cs}-137$ from $0,2 \mathrm{~Bq} / 1$ to $0,8 \pm 0,1 \mathrm{~Bq} / \mathrm{l}, \mathrm{Pu}-239 / 240$ from $0,002 \mathrm{~Bq} / \mathrm{l}$ to $0,006 \mathrm{~Bq} / \mathrm{l}$.

In a zone of the maximal radiation risk Am-241 from $0,1 \pm 0,02$ to 0,4 $\pm 0,01 \mathrm{~Bq} / \mathrm{l}, \mathrm{Cs}-137$ from $0,5 \mathrm{~Bq} / \mathrm{l}$ to $9,2 \pm 0,3 \mathrm{~Bq} / \mathrm{l}, \mathrm{Pu}-239 / 240$ from $0,002 \mathrm{~Bq} / 1$ to $0,032 \mathrm{~Bq} / 1$.

In a zone of minimum radiation risk Am-241 from 0,013 to 0,1 $\mathrm{Bq} / \mathrm{l}, \mathrm{Cs}-137$ from $0,1 \mathrm{~Bq} / 1$ to $1,7 \pm 0,02 \mathrm{~Bq} / \mathrm{l}, \mathrm{Pu}-239 / 240$ from 0,0001 Bq/l to $0,005 \mathrm{~Bq} / 1$.

Table 5: The maintenance of radionuclides in tests of meat

\begin{tabular}{|c|c|c|c|}
\hline \multirow[t]{2}{*}{ Inhabited point } & \multicolumn{3}{|c|}{ Volume activity of radionuclides, $\mathrm{Bq} / \mathrm{kg}$} \\
\hline & $\mathrm{Am}-241$ & Cs-137 & $\mathrm{Pu}-239 / 240$ \\
\hline \multicolumn{4}{|c|}{ beef } \\
\hline v. Bodene & $<0,5$ & $2,2 \pm 0,1$ & $0,056 \pm 0,001$ \\
\hline v. Sarapan & $0,52 \pm 0,01$ & $3,1 \pm 0,2$ & $0,034 \pm 0,001$ \\
\hline v. Sarzhal & $<0,3$ & $3,8 \pm 0,2$ & $<0,06$ \\
\hline v. Dolon & $<0,5$ & $4,3 \pm 0,2$ & $<0,05$ \\
\hline v. Mostik & $<0,2$ & $<1$ & $<0,02$ \\
\hline v. Zhanan & $<0,2$ & $6,5 \pm 0,5$ & $<0,08$ \\
\hline v. Begen & $0,45 \pm 0,01$ & $2,3 \pm 0,2$ & $0,032 \pm 0,001$ \\
\hline v. Abraly & $0,47 \pm 0,02$ & $2,8 \pm 0,2$ & $<0,008$ \\
\hline v. Semiyarka & $<0,5$ & $<1$ & $<0,02$ \\
\hline v. Kaynar & $<0,2$ & $0,6 \pm 0,2$ & $<0,005$ \\
\hline v. Akzhar & $<0,3$ & $0,8 \pm 0,4$ & $<0,007$ \\
\hline v. Kaskabulak & $<0,5$ & $1,5 \pm 0,2$ & $<0,003$ \\
\hline v. Beskaragay & $<0,2$ & $<1$ & $<0,001$ \\
\hline v. Novopokrovka & $<0,3$ & $0,8 \pm 0,2$ & $<0,05$ \\
\hline v. Karasu & $<0,2$ & $2,8 \pm 0,1$ & $<0,003$ \\
\hline c. Semey & $0,28 \pm 0,01$ & $1,7 \pm 0,3$ & $<0,006$ \\
\hline c. Ayaguz & $<0,02$ & $0,32 \pm 0,2$ & $<0,002$ \\
\hline v. Kiikkashkan & 0,32 & $1,9 \pm, 01$ & $<0,002$ \\
\hline v. Kokterek & $<0,2$ & $<0,2$ & $<0,005$ \\
\hline v. Karkaraly & $<0,03$ & $<0,3$ & $<0,003$ \\
\hline v. Makanshy & $<0,02$ & $0,5 \pm 0,2$ & $<0,0002$ \\
\hline v. Kokzhyra & $<0,01$ & $<0,2$ & $<0,0002$ \\
\hline v. Akku & $0,11 \pm 0,02$ & $<0,5$ & $<0,0003$ \\
\hline v. Kaskabulak & $<0,002$ & $<0,2$ & $<0,0005$ \\
\hline \multicolumn{4}{|c|}{ Horse-flesh } \\
\hline v. Bodene & $<0,5$ & $3,62 \pm 0,1$ & $<0,003$ \\
\hline v. Beskaragay & $<0,2$ & $1,25 \pm 0,1$ & $<0,001$ \\
\hline v. Sagyr & $<0,3$ & $2,24 \pm 0,2$ & $<0,001$ \\
\hline v. Shynkozha & $<0,1$ & $<1$ & $<0,001$ \\
\hline v. Zhantike & $<0,2$ & $<1$ & $<0,001$ \\
\hline \multicolumn{4}{|c|}{ Mutton } \\
\hline v. Mostik & $<0,2$ & $<1$ & $<0,02$ \\
\hline v. Kokbay & $<0,1$ & $<0,5$ & $<0,01$ \\
\hline v. Znamenka & $<0,1$ & $<0,5$ & $<0,05$ \\
\hline v. Mostik & $<0,05$ & $<0,1$ & $<0,0005$ \\
\hline v. Kokbay & $<0,03$ & $<0,2$ & $<0,0003$ \\
\hline
\end{tabular}

According to table 5 , it is visible that the presented production of livestock production contains slight quantity of radionuclides. In tests of beef from a zone of extreme radiation risk the content of Am-241 is from $0,2 \mathrm{~Bq} / \mathrm{kg}$ up to $0,51 \pm 0,01 \mathrm{~Bq} / \mathrm{kg}, \mathrm{Cs}-137$ from $1 \mathrm{~Bq} / \mathrm{kg}$ to $6,5 \pm 0,5 \mathrm{~Bq} / \mathrm{kg}, \mathrm{Pu}-239 / 240$ from $0,02 \mathrm{~Bq} / \mathrm{kg}$ to 0,08 $\mathrm{Bq} / \mathrm{kg}$. In the maximal zone of radiation risk Am-241 from 0,2 $\mathrm{Bq} / \mathrm{kg}$ to $0,47 \pm 0,02 \mathrm{~Bq} / \mathrm{kg}, \mathrm{Cs}-137$ from $0,6 \mathrm{~Bq} / \mathrm{kg}$ to $2,8 \pm 0,2$ $\mathrm{Bq} / \mathrm{kg}, \mathrm{Pu}-239 / 240$ from $0,001 \mathrm{~Bq} / \mathrm{kg}$ to $0,032 \mathrm{~Bq} / \mathrm{kg}$. In the raised zone of radiation risk Am-241 from $0,02 \mathrm{~Bq} / \mathrm{kg}$ to $0,32 \mathrm{~Bq} / \mathrm{kg}$, Cs137 from $0,32 \pm 0,2 \mathrm{~Bq} / \mathrm{kg}$ to $2,8 \pm 0,1 \mathrm{~Bq} / \mathrm{kg}, \mathrm{Pu}-239 / 240$ from $0,002 \mathrm{~Bq} / \mathrm{kg}$ to $0,05 \mathrm{~Bq} / \mathrm{kg}$. In tests of a minimum zone of radiation defeat of Am-241 from $0,002 \mathrm{~Bq} / \mathrm{kg}$ to $0,2 \mathrm{~Bq} / \mathrm{kg}, \mathrm{Cs}-137$ from $0,2 \mathrm{~Bq} / \mathrm{kg}$ to $0,5 \mathrm{~Bq} / \mathrm{kg}, \mathrm{Pu}-239 / 240$ from $0,0002 \mathrm{~Bq} / \mathrm{kg}$ to $0,005 \mathrm{~Bq} / \mathrm{kg}$.

In tests of horse-flesh from the village of Bodene the content of americium-241 is $0,5 \mathrm{~Bq} / \mathrm{kg}$, cesium- 137 of $3,62 \pm 0,1 \mathrm{~Bq} / \mathrm{kg}$, plutonium 239/240 0,003 of $\mathrm{Bq} / \mathrm{kg}$. In horse-flesh fromv. Beskaragay the maintenance of radionuclides of Am-241 of $0,5 \mathrm{~Bq} / \mathrm{kg}, \mathrm{Cs}-137$ of $1,25 \pm 0,1 \mathrm{~Bq} / \mathrm{kg}, \mathrm{Pu}-239 / 240$ of $0,001 \mathrm{~Bq} / \mathrm{kg}$. In horse-flesh of the v. Sagyr according to $0,3 \mathrm{~Bq} / \mathrm{kg}, 2,24 \pm 0,2 \mathrm{~Bq} / \mathrm{kg}, 0,001 \mathrm{~Bq} / \mathrm{kg}$; v.Shynkozha of $0,1 \mathrm{~Bq} / \mathrm{kg}, 1 \mathrm{~Bq} / \mathrm{kg}, 0,001 \mathrm{~Bq} / \mathrm{kg}$; v. Zhantik of 0,2 $\mathrm{Bq} / \mathrm{kg}, 1 \mathrm{~Bq} / \mathrm{kg}, 0,001 \mathrm{~Bq} / \mathrm{kg}$.

In tests of mutton the content of americium-241 is from $0,03 \mathrm{~Bq} / \mathrm{kg}$ up to $0,2 \mathrm{~Bq} / \mathrm{kg}$, cesium-137 from $0,1 \mathrm{~Bq} / \mathrm{kg}$ to $1 \mathrm{~Bq} / \mathrm{kg}$, plutonium-239/240 from $0,0003 \mathrm{~Bq} / \mathrm{kg}$ to $0,05 \mathrm{~Bq} / \mathrm{kg}$.

\section{Conclusion}

1. Radiometric control showed that, in all explored checkpoints of MED value, fluency of beta particles and EROA of a radon below a limit of admissible values. The MED level is from $0,05 \mu \mathrm{Sv} /$ hour up to $0,35 \mu \mathrm{Sv} /$ hour. EEC values of radon in rooms fluctuates from $44 \mathrm{~Bq} / \mathrm{m}^{3}$ to $195 \mathrm{~Bq} / \mathrm{m}^{3}$. The measured values of fluency of betta-particles in all the studied points are less than 10 freq/ $\min * \mathrm{~cm}^{2}$.

2. As a result an alpha - and scale of spectral analyses in tests of the soil, water of plants, meat and milk radionuclides of Am-241, Cs-137 and $\mathrm{Pu}-239 / 240$ found.

3. A specific activity of radionuclides in soils make Am-241 from $0,3 \pm 0,1 \mathrm{~Bq} / \mathrm{kg}$ to $91,5 \pm 1,8 \mathrm{~Bq} / \mathrm{kg}$, Cs-137 $0,5 \pm 0,1$ of $\mathrm{Bq} / \mathrm{kg}$ to $3658,6 \pm 22,5 \mathrm{~Bq} / \mathrm{kg}, \mathrm{Pu}-239 / 240$ from $0,005 \mathrm{~Bq} / \mathrm{kg}$ to $11,4 \pm 0,3$ $\mathrm{Bq} / \mathrm{kg}$; in Am-241 plants from $0,03 \mathrm{~Bq} / \mathrm{kg}$ to $25,8 \pm 0,2 \mathrm{~Bq} / \mathrm{kg}$, Cs137 from $0,2 \mathrm{~Bq} / \mathrm{kg}$ to $1150,3 \pm 10 \mathrm{~Bq} / \mathrm{kg}, \mathrm{Pu}-239 / 240$ from $0,0005 \mathrm{~Bq} / \mathrm{kg}$ to $2,2 \pm 0,2 \mathrm{~Bq} / \mathrm{kg}$; in Am-241 water from 0,002 Bq/1 to $0,15 \mathrm{~Bq} / \mathrm{l}, \mathrm{Cs}-137$ from $0,01 \mathrm{~Bq} / \mathrm{l}$ to $2,5 \pm 0,1 \mathrm{~Bq} / \mathrm{l}, \mathrm{Pu}-239 / 240$ from $0,0002 \mathrm{~Bq} / \mathrm{l}$ to $0,05 \mathrm{~Bq} / \mathrm{l}$; in Am-241 meat from $0,002 \mathrm{~Bq} / \mathrm{kg}$ to $0,52 \pm 0,01 \mathrm{~Bq} / \mathrm{kg}$, Cs-137 from $0,2 \mathrm{~Bq} / \mathrm{kg}$ to $6,5 \pm 0,5 \mathrm{~Bq} / \mathrm{kg}, \mathrm{Pu}$ - $239 / 240$ from $0,0002 \mathrm{~Bq} / \mathrm{kg}$ to $0,08 \mathrm{~Bq} / \mathrm{kg}$; in Am-241 milk from $0,013 \mathrm{~Bq} / \mathrm{l}$ to $2,3 \pm 0,2 \mathrm{~Bq} / \mathrm{l}$, Cs-137 0,1 up to $12,3 \pm 0,3 \mathrm{~Bq} / \mathrm{l}$, $\mathrm{Pu}-239 / 240$ from 0,0001 to $0,062 \pm 0,01 \mathrm{~Bq} / \mathrm{l}$.

\section{References}

[1] Kakimov A, Yessimbekov Z, Kakimova Z, Bepeyeva A, Stuart M (2016), Cs-137 in milk, vegetation, soil, and water near the former Soviet Union's Semipalatinsk Nuclear Test Site. Environmental Science and Pollution Research, 23(5), 4931-4937.

[2] Karabalin BK, Mukusheva MK, Kayrambayev SK (2001), Assessment of an average annual efficient dose of internal radiation of the population of the region of Semipalatinsk proving ground. NNC Bulletin, 3, 79-84.

[3] Logachev VA (2000), Nuclear tests at Semipalatinsk Test Site and their influence on a surrounding medium. NNC Bulletin, 3, 9-14.

[4] Law of the Republic of Kazakhstan of December 18, 1992 N 1787 XII. About social protection of the citizens who injured owing to nuclear tests at Semipalatinsk proving nuclear Test Site.

[5] Lukashenko SN (2010), The collection of works of Institute of Radiation safety and Ecology for 2007-2009. Pavlodar: Publishing house.

[6] Rikhvanov LP (2009), Radioelements in a surrounding medium and radioecology problems. Tomsk: STT.

[7] Complex studying of migration of radionuclides in the soil, water, plants, animals and influence of small chronic doses of radiation on biological objects in places of water manifestations of adits of the massif. The report on scientific and technical activity of Institute of radiation safety and ecology of SENTS RK executed on NTP 0346 "Development of nuclear power in the Republic of Kazakhstan" for 2007-2008: closing report. Lukashenko S.N. - Kurchatov: IRBE funds, 2008, $67 \mathrm{p}$.

[8] Spiridonov C, Mukusheva MK, Choubina OA, Solomatin VM, Yepifanov IE (2008), Assessment of population exposure doses as a result of a radio contamination of the territory of Semipalatinsk proving ground. Radiation biology. Radioecology, 48(2), 218-224.

[9] Balmukhanov SB, Abdrakhmanov JN, Balmukhanov TS, Gusev BI, Kurakina NN, Raisov TG (2006), Medical Effects and Dosimetric 
Data from Nuclear Tests at the Semipalatinsk Test Site /Technical Report for Defense Threat Reduction Agency. 124 p.

[10] Cherepnin YS (2000), The modern radiation situation on the former Semipalatinsk proving ground. Radioactivity at nuclear detonations: materials of the international conference. Moscow, 92-100.

[11] Duyssembaev S, Łozowicka B, Serikova A, Iminova D, Okuskhanova E, Yessimbekov Z, Kaczyński P (2014), Radionuclide content in the soil-water-plant-livestock product system in East Kazakhstan. Polish Journal of Environmental Studies, 23(6). 19831993.

[12] Kakimov A, Zharykbasov Y, Kakimova Z, Yessimbekov Z, Mirasheva G, Baybalinova M, Smirnova I (2017), Specific activity of Cs-137 in milk of Semey region of East Kazakhstan area. Annual Research \& Review in Biology, 12(5), ARRB-33391. 